\title{
WIERSZE TOMASZA AUGUSTA OLIZAROWSKIEGO (ZE ZBIORÓW UKRAIŃSKIEJ BIBLIOTEKI NARODOWEJ IM. WOŁODYMYRA WERNADSKIEGO W KIJOWIE)
}

\author{
Albert Nowacki \\ Katolicki Uniwersytet Lubelski Jana Pawła II, Lublin, Polska \\ ORCID: 0000-0002-2418-0574
}

\begin{abstract}
Streszczenie. W niniejszym artykule przedstawiono sylwetkę polskiego romantyka, przedstawiciela „ukraińskiej szkoły” w literaturze polskiej, a zarazem wybitnego działacza społeczno-kulturalnego na emigracji, Tomasza Augusta Olizarowskiego. W pierwszej części pracy autor przedstawia wybrane elementy biografii pisarza, jego sylwetkę twórczą oraz najważniejsze dzieła literackie. Druga część niniejszego artykułu zawiera rozważania na temat rękopisu wierszy, odnalezionego w Dziale Rękopisów Ukraińskiej Biblioteki Narodowej im. Wołodymyra Wernadskiego w Kijowie. Konfrontacja znaleziska z istniejącym stanem wiedzy pozwoliła na skorygowanie kilku nieścisłości, zwłaszcza odnośnie do tytułów wspomnianych wierszy. Praca stanowi skromny wkład do badań nad spuścizną literacką T.A. Olizarowskiego.
\end{abstract}

Słowa kluczowe: „szkoła ukraińska” w literaturze polskiej, poezja, wiersze, romantyzm, emigracja.

Romantyzm w literaturze polskiej to zagadnienie przebadane gruntownie i wszechstronnie, by wymienić takich wybitnych znawców, jak chociażby Juliusz Kleiner, Czesław Zgorzelski czy Maria Janion. Nie mniej rzetelnie zbadany został swoisty fenomen literacki, którym w okresie romantyzmu była bez wątpienia ,szkoła ukraińska” w literaturze polskiej - zjawisko rozpoznane, zdefiniowane i, jak się wydaje, nazwane po raz pierwszy przez Aleksandra Tyszyńskiego, który pisał o niej tymi słowy:

Duch i styl Ukraińskiej Szkoły różne są zupełnie od ducha i stylu Szkoły Liteskiej, a bardziej jeszcze innych poezij polskich. Ponurość, dzikość, krwawe obrazy, zbrodnie, są ulubioną, powszednią Poetów Ukraińskich treścią; jeśli w nich spotkasz niekiedy uśmiechający się obraz, nie uśmiechaj się wcale, bowiem gorzko opłacisz tę chwilową radość; jeżeli w nich spotkasz miłość, miłość będzie ponura, lub dzika, albo też cielesna i prosta. Przedmioty i obrazy Ukraińskiej Szkoły z wielu względów świat nowy dla poezii polskiej stworzyły; Atamany, Kozaki, Tatary, stepy, porohy, czajki, ukraińskie miasteczka i ukraińskie rzeki, po raz pierwszy dały się słyszeć, dały się widzieć w jej tworach. Styl ukraińskich poetów wszędzie nierówny, niepoprawny, ciemny; rymy to nazbyt trudne, to cał- 
kiem zaniedbane; odznaczają go słowa silne, ponure i nieraz nadęte, porównania ciężkie, dalekie, mocno poetyczne; mnóstwo wyrazów nowych, miejscowych; niezwykłe obróty i składnie $[\ldots]^{1}$.

Do grona twórców z kręgu „szkoły ukraińskiej” Aleksander Tyszyński zaliczył w pierwszej kolejności Antoniego Malczewskiego, Bohdana Zaleskiego, Maurycego Gosławskiego oraz Seweryna Goszczyńskiego, zaś Michał Grabowski dodawał jeszcze Tymona Zaborowskiego, Aleksandra Grozę, Tomasza Padurę oraz Tomasza Augusta Olizarowskiego². Należy podkreślić, iż wspomniani pisarze wnieśli do literatury polskiej nową tematykę, swoisty koloryt, nowe motywy, pejzaże, nowe postacie literackie, dzięki czemu, jak zauważa Roman Kyrcziw, wydatnie przyczynili się do ugruntowania romantyzmu polskiego ${ }^{3}$.

Wspomniany Tomasz August Olizarowski jest tym przedstawicielem „szkoły ukraińskiej”, który dziś został już nieco zapomniany i wciąż nie doczekał się ani solidnych opracowań naukowych, ani też jakiegoś bardziej pełnego wydania jego utworów, albowiem, jak zauważa Małgorzata Burzka-Janik, „większość jego tekstów pozostaje wciąż jedynie w rękopisach znajdujących się w Bibliotece Polskiej w Paryżu i Bibliotece Kórnickiej”" . Warto mieć na uwadze, że spuścizna literacka tego twórcy jest niezwykle pokaźna, obejmuje bowiem kilkanaście poematów, kilkanaście dramatów oraz kilka zbiorów liryków i wierszy okolicznościowych; jest też różnorodna zarówno pod względem gatunkowym, jak również i tematycznym, i choć niektórzy są skłonni twierdzić, że dotychczas wydane teksty to ,[...] mieszanina niewielu dobrych i oryginalnych utworów z poronionymi płodami grafomanii $[\ldots]$ ". jednak inni upatrują $\mathrm{w}$ nim poety utalentowanego ${ }^{6}$, którego cechuje nie tylko „nieskazitelny język”, ale i szczerość wypowiedzi wypływająca „z głębokiego przeżycia zdarzeń i prawdziwego wzruszenia"”.

A. Tyszyński, O szkołach poezii polskiej, [w:] Idem, Amerykanka w Polsce. Romans, cz. 2, St. Petersburg 1837, s. 46-47. Tu i w dalszej części artykułu zachowano pisownię oryginału.

2 Zob. M. Grabowski, O szkole ukraińskiej poezyi, [w:] Idem, Literatura i krytyka, Wilno 1839, s. 11. Zob. też: M. Bielanka-Luftowa, Znaczenie terytorium w tak zwanej szkole ukraińskiej, „Pamiętnik Literacki” 1936, z. 2, s. 362; M. Rudkowska, Tomasza Augusta Olizarowskiego szansa na dramat narodowy, „Teksty Drugie” 1998, nr 5, s. 125-126.

3 Р. Кирчів, , Українська школа” польського романтизму в контексті міжнаціональних фольклорно-літературних взаємин, „Київські полоністичні студії”, t. V: Романтизм: між Україною та Польщею, Київ 2003, s. 22.

4 M. Burzka-Janik, Mistyczna frenezja. Czarny romantyzm Tomasza Augusta Olizarowskiego, [w:] T.A. Olizarowski, Poematy, red. M. Burzka-Janik, J. Ławski, Białystok 2014, s. 9.

5 J.W. Gomulicki, Tomasz August Olizarowski (1811-1879), „Poezja” 1983, nr 11-12, s. 8.

6 Zob. M. Grabowski, op. cit., s. 18.

7 Z. Markiewicz, T. Sivert, Melpomena polska na paryskim bruku. Teatralia polskie we Francji w XIX wieku, Warszawa 1973, s. 9. 
W XIX tomie Encyklopedii Powszechnej z 1865 roku znajduje się niewielka notatka, z której można się dowiedzieć, że Tomasz Olizarowski przyszedł na świat w 1814 roku na Wołyniu. ${ }^{8}$. Nie jest to jednak informacja prawdziwa, albowiem wszelkie inne źródła podają, że urodził się w roku $1811 \mathrm{w}$ miejscowości Wojsławice na Rzeszowszczyźnie9. Ojcem przyszłego poety był Jakub Olizarowski, oficer w legionach Dąbrowskiego w Hiszpanii, matka, de domo Aleksandrowicz o imieniu nieznanym ${ }^{10}$. Seweryna Duchińska, bliska znajoma i zarazem autorka jednej z pierwszych biografii pisarza, wspomina, że po zakończeniu okresu służby wojskowej ojca rodzina Olizarowskich osiadła czasowo w Galicji, jednak zaraz dodaje, że ,oboje nie byli wpisani w galicyjską ludność: właściwém ich gniazdem był Wołyń. Gdy syn podrósł, oddali go zatém do słynnéj szkoły Krzemienieckiéj, założonéj przez Tadeusza Czackiego""11.

We wspomnieniach współczesnych młody Tomasz jawił się jako chłopiec o nieprzeciętnych zdolnościach, nie dziwi więc, że rodzice, zdobywając się na spory dla nich wysiłek finansowy, postanowili oddać wówczas dwunastoletniego syna na naukę do wspomnianej już szkoły w Krzemieńcu. Seweryna Duchińska pisze, że w pierwszych latach nauki ujawniły się jego niebywałe zdolności matematyczne, a dopiero później zaczął wykazywać zainteresowanie poezją. Jak jednak przyznaje autorka biografii,

Późniéj obudziła się w nim chęć do poezyi: nauka matematyki dzielnie mu posłużyła do normalnego układu zgłosek i do ścisłego obliczania się z myślą, jaką pragnął wyrazić. Wiersz jędrny, jakby wyrąbany, podobał się towarzyszom: obsypali go oklaskami ${ }^{12}$.

8 Olizarowski (Tomasz August), [w:] Encyklopedyja powszechna, t. XIX: Msta. - Optymaci., Warszawa 1865, s. 878.

9 Olizarowski Tomasz August (1811-1879), [w:] Dawni pisarze polscy od poczatków piśmiennictwa do Młodej Polski. Przewodnik biograficzny i bibliograficzny, t. 3: Mia-R, Warszawa 2002, s. 175; Olizarowski Tomasz August, [w:] Polski stownik biograficzny, t. XXIII: Niemirycz Władysław - Olczak Wacław, Wrocław - Warszawa - Kraków - Gdańsk 1978, s. 823; Zbiór poetów polskich XIX w., ułożył i opracował P. Hertz, ks. II, Warszawa 1959, s. 593; S. Duchińska, Tomasz August Olizarowski, [w:] Biblioteka Warszawska, t. IV, Warszawa 1897, s. 3. O kłopotliwych faktach w życiorysie T.A. Olizarowskiego, w tym także odnośnie do miejsca i daty urodzin, szczegółowo pisała Małgorzata Burzka-Janik, zob. Eadem, op. cit., s. 17-19. 10 Olizarowski Tomasz August (1811-1879), [w:] Dawni pisarze polscy od poczatków piśmiennictwa do Młodej Polski, s. 175. Jedyna informacja na temat imienia matki pochodzi z przemowy pogrzebowej przyjaciela Olizarowskiego, Kanuta Gorkowskiego, który stwierdził, iż „Tomasz Olizarowski urodził się 10 marca 1811 r. we Wojełowicach (sic!) w Rzeszowskiem, w Galicji, z ojca Jakuba, zasłużonego legionisty, i z Johanny z Aleksandrowiczów, matki”, zob. Przemówienie K(anuta) Gorkowskiego nad grobem T(omasza) Olizarowskiego w Montmorency 21 maja 1886 r., „Poezja” 1983, nr 11-12, s. 196.

11 S. Duchińska, op. cit., s. 3.

12 Ibidem. Na temat okresu krzemienieckiego w życiu T.A. Olizarowskiego zob. też: A.E. Kamińska, Krzemieniec Tomasza Augusta Olizarowskiego, „Rocznik Towarzystwa Literackiego imienia Adama Mickiewicza" 2005, nr 40, s. 155-168. 
Początki nauki nie były jednak okresem łatwym, gdyż jego nieprzeciętne zdolności musiały w końcu wywołać uczucie zazdrości i zawiści wśród kolegów. Seweryna Duchnińska przytacza liczne przypadki dokuczania młodemu Tomaszowi, zwłaszcza z powodu zamiłowania do pisania wierszy ${ }^{13}$. Owe doświadczenia wpłynęły, jak pisze M. Burzka-Janik, na kształtowanie się samotniczego charakteru Dydyma: ,poeta bowiem zamknął się w sobie, odizolował (miał nawet przez ponad pół roku nie jadać we wspólnej stołówce), ponad dwa lata pozostał „na uboczu”. Nie przestał jednak pisać. Przyjaciół znalazł wśród samych wykładowców"14.

Jeśli wierzyć notatce z Encyklopedii Powszechnej, jako pierwszy na talencie Olizarowskiego poznał się Józef Korzeniowski, będący miejscowym profesorem języka i literatury polskiej, doceniając jego zdolności i pasje, postanowił wziąć go pod swoje skrzydła ${ }^{15}$. Fakt ten potwierdza także S. Duchińska ${ }^{16}$. Wspomniana okoliczność przyniosła równocześnie zmianę stosunku kolegów do młodego poety, albowiem publicznie okazywany szacunek ze strony nauczyciela musiał wreszcie zaowocować respektem ze strony kolegów, którzy, jak pisze Marian Dubiecki, okrzyknęli go mianem „poety ówczesnej młodzieży licealnej”"17.

Tomasz Olizarowski ukończył Liceum Krzemienieckie 10 marca 1830 roku, mając dziewiętnaście lat, i kiedy wybuchło powstanie listopadowe, natychmiast zasilił szeregi powstańców, wstępując najpierw do korpusu generała Józefa Dwernickiego, który w tym czasie przybył na Wołyń, a następnie walcząc w Legii Litewsko-Ruskiej ${ }^{18}$, w składzie której pozostawał aż do upadku powstania.

Fiasko zrywu narodowego zmusiło Olizarowskiego i jemu podobnych do opuszczenia zaboru rosyjskiego i ukrywania się w Galicji. Niewiele wiadomo na temat galicyjskiego wygnania pisarza, choć istnieją świadectwa mówiące o tym, iż działając w okolicach Lwowa, przygotowywał wznowienie powstania. Jak pisze S. Duchińska,

Ta burza nasamprzód pchnęła go do Galicyi. Trzy lata przepędził we Lwowie, ztąd rzucił w świat pełen życia i siły poemat, wysnuty z życia ukraińskiego ludu. Mówimy tu o powieści Zawerucha ${ }^{19} ;[\ldots]$ Po trzyletnim pobycie w Galicyi, poeta

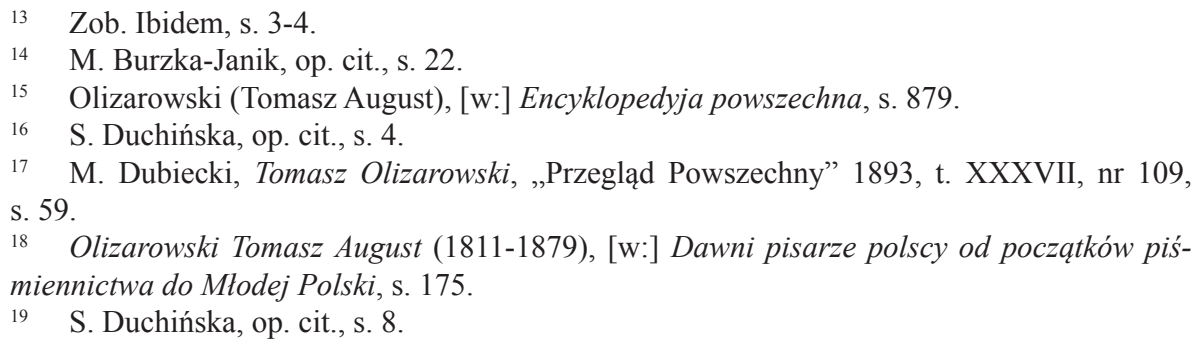


zmuszony opuścić Lwów, rzucony burzą pod obce niebo, uczuł boleśnie swe sieroctwo i osamotnienie ${ }^{20}$.

Za udział w powstańczym zrywie Olizarowski został aresztowany w 1835 roku przez policję austriacką i spędził pół roku w cytadeli w Trieście, skąd deportowano go następnie do Anglii, gdzie przeżył kolejne dziewięć lat życia. Okres londyński wypełniła mu intensywna praca literacka, podczas której, jak pisze M. Burzka-Janik, ,,wydany zostaje tomik poezji pod tytułem Egzercycje poetyckie, a w nim poemat Krzyż w Peredylu (wydanie nast. z 1852 roku, zmienione jako Topir-Góra). Także w tym roku poeta tworzy Grafa Wołodego, epilog komedii (1842) oraz Wolodego. Tragedię romantyczna w 6 odstonach (1844), pisze powieść hebrajską Softy, przerabia stare utwory (w tym poematy, na przykład Bruno), a w latach 1838-1839 współpracuje z ,Tygodnikiem Literackim" wychodzącym w Poznaniu"21. Oprócz tego udzielał się społecznie, brał udział w życiu politycznym i jako stronnik Adama Czartoryskiego został jednym z ideologów Hotelu Lambert.

W 1845 roku Olizarowski przeprowadził się do Paryża, gdzie, oprócz działalności społeczno-politycznej, zajmował się również twórczością literacką. W tym właśnie okresie powstały trzy zbiorki poetyckie (Hejnat, Tyrtejka, Woskresenki). Warto nadmienić, iż dość dużą nadzieję pokładał poeta właśnie w Woskresenekach, które były próbą, w dodatku, jak twierdzi Andrzej Tchórzewski, „najbardziej udaną” powrotu do romantycznej twórczości z lat młodzieńczych ${ }^{22}$. Myśl A. Tchórzewskiego podziela również Andrzej Zieniewicz, który nie tylko wysoko ocenił ten zbiorek poetycki, ale również zwrócił uwagę na to, że Olizarowski stworzył w nim kresową legendę z punktu widzenia Europy: ,jego wyobraźnia - zaiste homerycka - tworzy z kresowych motywów rapsody, fragmenty wielkiej historii, freski z dziejów Słowiańszczyzny, opowieść o walce dwóch światów. Perspektywą, z której coś widać, staje się przestrzeń mitu słowiańskiego, którego formą jest epos Przedmurza"23.

Przebywając w Paryżu, Olizarowski zawarł znajomość z Adamem Mickiewiczem i pod wpływem tego spotkania zaczął kształtować się w nim kult polskiego wieszcza do tego stopnia, iż poświęcił mu dwa wiersze (Wiersz do... [Blask twego geniuszu przeszedt po mych piórach...] oraz Wiersz do A... M... [Zagraj, zagraj, a zaśpiewaj...]), a następnie przełożył na język polski

\footnotetext{
20 Ibidem, s. 15.

21 M. Burzka-Janik, op. cit., s. 32. W tym miejscu warto odnieść się do utworu Softy: wprawdzie sam T.A. Olizarowski nazywa go ,powieścią” (zob. T.A. Olizarowski, Dzieła, t. 1, Wrocław 1852), niemniej jednak nie jest to powieść w tradycyjnym rozumieniu gatunkowym, lecz raczej poemat wierszem.

22 Zob. A. Tchórzewski, Dwaj poeci. Kroki z korytarza nicości, „Poezja” 1983, nr 11-12, s. 115 .

23 A. Zieniewicz, Biedna, romantyczna dusza, „Poezja” 1983, nr 11-12, s. 14.
} 
dwa francuskojęzyczne dramaty Mickiewicza: Konfederaci barscy i Jakub Jasiński albo dwie Polski.

Pod wpływem wydarzeń Wiosny Ludów w 1848 roku Olizarowski opuścił Paryż z zamiarem udania się do Galicji, jednakże udało mu się dotrzeć jedynie do Drezna, a stamtąd - przyjmując zaproszenie od gen. Dezydera Chłapowskiego - do Turwii w Wielkopolsce, gdzie spędził trzy kolejne lata. Dla poety był to czas niezwykle płodny, jednakże jego sielankę przerwało wydalenie z Księstwa Poznańskiego z powodu przedstawionych mu przez rząd pruski zarzutów o konspirację. Następnym, sześcioletnim, przystankiem w życiu poety było kolegium jezuickie w Tirlemont w Belgii, gdzie przyjął posadę nauczyciela języka i literatury polskiej. Rok 1858 ponownie zastał Olizarowskiego w Paryżu, jednak tym razem jego życie upływało w osamotnieniu, niedostatku i chorobie. W 1864 roku został on pensjonariuszem Domu św. Kazimierza w Ivry pod Paryżem, będącym w rzeczywistości finansowanym przez Czartoryskich zakładem opieki społecznej dla polskich emigrantów ${ }^{24}$; tutaj też zaprzyjaźnił się z Cyprianem Kamilem Norwidem, który również był mieszkańcem tego zakładu.

Wprawdzie ostatnie lata życia Olizarowskiego upłynęły w biedzie, ale też były okresem pracowitym. Większość czasu zabierało mu przepisywanie oraz poprawianie własnych dzieł, pisanie dramatów i prowadzenie obszernej korespondencji, a także przepisywanie dokumentów urzędowych, co było sposobem na dorobienie do skromnego zasiłku². Poeta zmarł 3 maja 1979 roku w Ivry, gdzie został pochowany, a dopiero w 27 maja 1886 roku trumnę $\mathrm{z}$ jego prochami przeniesiono do polskiego grobu zbiorowego na cmentarzu Montmorency.

Biografia Olizarowskiego była charakterystyczna dla całego pokolenia, któremu dane było żyć w tamtych czasach. Co znamienne, biografia ta jest niekompletna, wiele składających się na nią świadectw pozostaje w jawnej ze sobą sprzeczności, a których, jak się wydaje, dziś zweryfikować się nie da. Podobny los spotkał też spuściznę literacką poety, która nigdy nie została w pełni wydana, a nawet te utwory, którym dane było ukazać się drukiem, pozostają w znacznym rozproszeniu. Małgorzata Burzka-Janik zauważyła, że żadna z polskich bibliotek nie dysponuje choćby jednym kompletem już wydanych dzieł Olizarowskiego, rozproszone są także niezbyt liczne opracowania, recenzje i próby biograficzne, nie istnieje też żaden wykaz powyższych pozycji ${ }^{26}$. Podobnie wygląda los jego licznych rękopisów, które - niewydane i nieopracowane - spoczywają w archiwach w Paryżu, Warszawie, Kórniku oraz Kijowie.

\footnotetext{
24 Olizarowski Tomasz August (1811-1879), [w:] Dawni pisarze polscy od początków piśmiennictwa do Młodej Polski, s. 175.

25 M. Burzka-Janik, op. cit., s. 42.

26 Ibidem, s. 13-14.
} 
Powodem, dla którego powstała niniejsza praca, jest przypadkowe znalezisko w Dziale rękopisów Ukraińskiej Biblioteki Narodowej im. Wołodymyra Wernadskiego, znajdującego się na ulicy Wołodymyrskiej 62 w Kijowie. Przy okazji kwerendy poświęconej ujawnieniu poloniców w zasobach archiwów ukraińskich natrafiono na teczkę o sygnaturze $\Phi$ XXIV, 2600. Opis wspomnianej teczki nie zawierał żadnych informacji o autorze, zamieszczono w nim jedynie tytuł w języku polskim (,Do Polski”) z dopiskiem w języku rosyjskim („и другие стихотворения”) oraz adnotację, że zawiera ona utwory z lat $1833-1879$. Zawartość teczki to 21 wierszy napisanych starannym, kaligraficznym niemal pismem. Po dość długich poszukiwaniach udało się nareszcie zidentyfikować autora wspomnianych utworów, którym okazał się Tomasz August Olizarowski.

W rezultacie dalszych dociekań udało się ujawnić artykuł Wołodymyra Wasyłenki o nieznanych polonicach w ukraińskich archiwach, w którym autor również wspomina o odnalezieniu wspomnianego zbioru ${ }^{27}$ oraz podaje tytuły wierszy Olizarowskiego: Do Polski, Nieco o zimie, Ze świata pieśni, Do *** (Sposób na pieśń auzońska), Lekarstwo, Do Polek nawiedzajacych starców w Domu św. Kazimierza w Paryżu, Do człowieka dobrego, Do czarnomorskiej ostoi, Poczta rosyjska, Rozmowa z czasem, Wieńce, Odźwierna Ducha, Do astmy, Pożegnanie jaskótki, Nice, Palma, Błędna mara, Do lechijskiej dziewicy, Kurhan aladyński, Do muz, Sosny polskie ${ }^{28}$.

Na wspomniany artykuł W. Wasyłenki powołuje się także polska badaczka twórczości Olizarowskiego, M. Burzka-Janik, która za ukraińskim uczonym wymienia wspomniane utwory w swojej pracy w przypisie nr $20^{29}$. Analiza wspomnianych materiałów ujawniła jednak pewne nieścisłości, które w tym miejscu postaramy się skorygować. Wołodymyr Wasyłenko przedstawia nieco inną kolejność wierszy znajdujących się we wspomnianej teczce ${ }^{30}$, oprócz tego uwagę zwracają inne niż w rękopisach tytuły wierszy. Pomyłki dotyczą wiersza Do czarnomorskiej ostoi, który w oryginale brzmi $S$ czarnomorskiej ostoi (dokument $\mathrm{nr} 5$ ), różni się także zapis tytułów dwóch innych utworów: Poczta rosyjska (zamiast Poczta rossyjska, ten sam numer dokumentu) oraz Nice (zamiast Nica, dokument nr 8). Pomyłki owe mogą wynikać z różnych

\footnotetext{
27 W. Wasilenko, Nieznane polonica w ukraińskich archiwach, „Ruch Literacki” 1993, nr 4, s. 455-456.

28 Ibidem.

29 Zob. M. Burzka-Janik, op. cit., s. 13.

30 Prawidłowa, zgodna z numeracją dokumentów kolejność, jest następująca: Do Polski, Nieco o zimie, Ze świata pieśni, Do *** (Sposób na pieśń auzońska), Lekarstwo, Wieńce, Do Polek nawiedzających starców w Domu św. Kazimierza w Paryżu, Do człowieka dobrego, Do czarnomorskiej ostoi, Poczta rossyjska, Odźwierna Ducha, Rozmowa z czasem, Do astmy, Pożegnanie jaskótki, Nica, Palma, Błędna mara, Do Lechijskiej dziewicy, Kurhan aladyński, Sosny polskie. Do muz, zob. DRUBNWW, sygn. Ф. XXIV, 2600.
} 
względów - z błędu popełnionego przez samego W. Wasyłenkę (zwłaszcza z odczytania ozdobnego „S” jako „Do” albo też z chęci polskiego tłumacza (oryginalny tekst ukraińskiego badacza został napisany po rosyjsku, zaś na język polski przełożył go J. Dębski) do zapisania tytułu utworu współczesną polszczyzną.

Warto przy okazji zwrócić uwagę na pewną kontaminację, do jakiej doszło w pracy M. Burzki-Janik, która, przytaczając wymienione przez W. Wasyłenkę wiersze, jeden z nich zapisała $\mathrm{w}$ ten sposób: „Do*** (Sposób na pieśń luzońska)" ${ }^{31}$ zamiast „Do*** (Sposób na pieśń auzońska)”. Owa zamiana niosłaby za sobą daleko idące konsekwencje zmiany wydźwięku tego utworu, albowiem osadzałaby go w zupełnie odmiennej przestrzeni geograficznej. Jak podaje Elektroniczny stownik języka polskiego XVII $i$ XVIII wieku, przymiotnik ,auzoński” (inny wariant fonetyczny: ,awzoński”) jest wyrazem utworzonym od rzeczownika „Auzonia” i oznacza "związany z Italią; włoski; łaciński' ${ }^{32}$. Potwierdza to również Stownik łacińsko-polski ks. Floriana Bobrowskiego, który zawiera takie hasła, jak „Ausonǐa - część Włoch nadmorska, kraj Auzoński, Auzonja, czyli Włochy” oraz „Ausonǐus - Auzoński, należący do Auzonji, Włoski, Łaciński, Rzymski [...]”33. Przymiotnik „luzoński” odnosi się zaś do wyspy Luzon, będącej częścią archipelagu Filipin. Nie ma powodu przypuszczać, by znająca przecież gruntownie spuściznę literacką Olizarowskiego polska badaczka świadomie dopuściła się takiej istotnej pomyłki, jej wyjaśnienia należy raczej upatrywać albo w automatycznych modułach sprawdzania pisowni polskiej, które faktycznie wyraz „luzoński” proponują jako zamiennik dla wyrazu ,auzoński”, albo też jako prozaiczny rezultat popełnienia pospolitej „literówki”.

Po wyjaśnieniu kwestii technicznej przychodzi czas, by spojrzeć już na same wiersze Olizarowskiego. $\mathrm{Z}$ formalnego punktu widzenia 11 utworów, a więc Lekarstwo, Wieńce, Do Polek nawiedzajacych starców w Domu św. Kazimierza w Paryżu, Odźwierna Ducha, Rozmowa z czasem, Pożegnanie jaskótki, Palma, Błędna mara, Do lechijskiej dziewicy, Kurhan aladyński oraz Sosny polskie stanowią klasyczne sonety, liczą bowiem 14 wersów podzielonych na dwie czterowersowe i dwie trzywersowe strofy ${ }^{34}$. Pozostałe wiersze (Do Polski, Nieco o zimie, Ze świata pieśni, Do *** (Sposób na pieśń auzońska), Do człowieka dobrego, Do czarnomorskiej ostoi, Poczta rossyjska, Do astmy, Do muz) składają się z dwóch zwrotek czterowersowych oraz trzech dystychów. Wyjątek stanowi wiersz Nica, który posiada trzy zwrotki cztero-

Zob. M. Burzka-Janik, op. cit., s. 13.

Elektroniczny stownik języka polskiego XVII i XVIII wieku, [w:] Polska Akademia, Instytut Języka Polskiego, [strona www:] http://sxvii.pl/index.php?strona=haslo\&id_hasla=2287 [dostęp: 22.09.2017 r.].

33 Ks. F. Bobrowski, Stownik tacińsko-polski, wyd. 3, Wilno 1905, s. 509.

34 Por. A. Kulawik, Poetyka. Wstęp do teorii dzieła literackiego, Kraków 1997, s. 180. 
wersowe i jeden dystych. Ulubionym systemem wersyfikacyjnym autora jest trzynastozgłoskowiec, ale wykorzystuje też jedenastozgłoskowiec (Ze świata pieśni, Do *** (Sposób na pieśń auzońska), Do astmy, Do muz) oraz ośmiozgłoskowiec (Pożegnanie jaskółki).

Już po dość pobieżnej lekturze wierszy Olizarowskiego można odnieść wrażenie, że jest to liryka opisowa, wydaje się ponadto, że zarówno tematyka powyższych utworów, kolejność ich ułożenia, a także dobór środków stylistyczno-intonacyjnych i sposób obrazowania świadczą o tym, że nie mamy do czynienia z przypadkowymi tekstami, ale, jak powiada W. Wasyłenko, ,,z tradycyjnym dla poety dążeniem do stworzenia jednolitego artystycznie cyklu, w którym na płaszczyźnie lejtobrazów i lejtmotywów każdy z wierszy zyskuje jakby dopełniające go metaznaczenie. Pomimo częstych przeciwieństw w obrębie treści teksty te uzupełniają się wzajemnie i nadają całości charakter medytacyjny ${ }^{35}$.

Otwierającym ,cykl” poetycki utworem jest wiersz Do Polski. Nie dziwi wcale taki wybór poety, albowiem, jak pamiętamy, był on wychowankiem Liceum Krzemienieckiego, w którym odebrał rzetelne wychowanie w duchu patriotycznym, i które ukształtowało w nim odpowiednią postawę wobec ,ideologicznej ojczyzny" ". Jak słusznie bowiem zauważył Wołodymyr Jerszow, „саме Кременцю впродовж ХІХ століття судилося зіграти провідну роль у розвитку освіти, науки й культури краю. Саме Кременецький ліцей став колискою літературної самобутності ряду письменників Правобережжя доби романтизму" ${ }^{37}$. W wierszu tym pobrzmiewa jednak gorycz, albowiem podmiot liryczny skarży się, że jego matka-Ojczyzna nie kocha swego syna, walczącego przecież o jej niepodległość, zamiast tego jest dlań raczej złą, odtrącającą macochą:

Matko, tyś mi macochą! Lecz dławią się skargi;

Łza wytrysnęła serdeczna; ścięły mi się wargi:

I dla ciebie u matki macierzyństwa niéma;

I ty w świecie masz tylko srogiego ojczyma! ${ }^{38}$.

W przytoczonych strofach pobrzmiewa nie tylko nostalgia, ale też żal za utraconą ojczyzną oraz wyrzut, iż pomimo ofiary złożonej na jej ołtarzu poeta musi się kryć, uciekać i tułać po świecie, który jest dla niego „,srogim ojczy-

35 W. Wasilenko, op. cit., s. 456.

36 Н. Варфоломеєва, Ratio contra cordo. Генеза образу „слов'янської вітчизни” y творчості Томама Августа Олізаровського, „Київські полоністичні студіі” 2011, t. 18, s. 168

37 В. Єршов, Волинський простір у мемуаристичній літературі Правобережжя, „Волинь-Житомирщина”. Історико-філологічний збірник з регіональних проблем, $\mathrm{nr}$ 17, Житомир 2007, s. 25.

38 T.A., Olizarowski, Do Polski, [w:] DRUBNWW, sygn. Ф. XXIV, 2600, dok. nr 1. 
mem". Jeszcze wyraźniej nutki nostalgii za utraconym domem rozbrzmiewają w wierszach Nieco o zimie oraz Pożegnanie jaskótki, czyli motywami niewątpliwie przywodzącymi na myśl niepowtarzalną polską przyrodę. Jednocześnie obydwa utwory, a zwłaszcza Nieco o zimie, pokazują, że podmiot liryczny snuje rozważania o upływie czasu. Wspomina, że zima to wspaniała pora roku dekorująca świat srebrem i bielą i „Choć smutna była pora i srogie żywioły”, to jednak , ,...] w stronę smutku leciałem wesoły./ Zimo, lubiłem ciebie za mej wiosny czasu" ${ }^{39}$. Najzimniejsza pora roku obfitowała w mnóstwo inspiracji, odświeżała myśli, jednak po latach, w miarę upływu czasu, przynosiła już tylko chłód dla starszego człowieka i nastrajała do mocno egzystencjalnych rozważań: „Ongi, miały rozbudę dumki moje w tobie;/ Dziś, ochoty do życia wolą szukać w grobie" ${ }^{40}$. Trudno nie oprzeć się wrażeniu, że jest to wiersz powstały w jesieni życia poety, najprawdopodobniej, jak sugeruje W. Wasyłenko, w przytułku św. Kazimierza w Ivry ${ }^{41}$.

Największe jednak wrażenie wywiera noszący widoczne echa wpływu „szkoły ukraińskiej” wiersz Błędna mara, w którym można odnaleźć wyraźne motywy egzystencjalne i w którym podmiot liryczny nie tylko wyraża tęsknotę za krajem rodzinnym, ale też mówi o ułudzie i ulotności sławy:

Na Wołyniu, nad Ikwą, pod niebem majowem,

Kiedy mnie wszystko jeszcze trzymało przy szkole,

Łudzicielka szepnęła: wyleć na me pole,

Znajdziesz wielkie tam szczęście z wielkim życiem nowem.

Więc na wiekim się rozstał ze szczęściem domowem.

W świat uniosły mię pióra pawie i sokole;

$Z$ burzą za sławą nosząc nadzieje i bole,

W stolicym świata osiadł widmem przygrobowem.

O! sławo! czarodziejko! dziś ty błędną marą

Przychodzisz poswawolić z moją myślą starą.

Lecz już twoja swawola urzec mię niezdoła.

Ofiary tobie składać starość niepozwala.

Zdala więc, czarodziejko, bądź odemnie, zdala!

Przyczepiaj swe uroki do młodego czoła ${ }^{42}$.

Odnalezione w Kijowie utwory Olizarowskiego są w zdecydowanej swej większości przejmujące, dominują w nich bowiem nie tylko wspomnienia z dzieciństwa poety, refleksje na temat ojczyzny, ale także próba dokonania rozliczenia z przeszłością, z teraźniejszością. Tadeusz Sivert podkreślał, że

\footnotetext{
T.A., Olizarowski, Nieco o zimie, [w:] DRUBNWW, sygn. Ф. XXIV, 2600, dok. nr 1. Ibidem.

W. Wasilenko, op. cit., s. 455.

42 T.A. Olizarowski, Błędna mara, [w:] DRUBNWW, sygn. Ф. XXIV, 2600, dok. nr 9.
} 
„liryka ostatnich lat życia poety ma charakter bardzo osobisty. Jest w niej uczucie żalu z powodu utraconych nadziei, pojawia się skarga na samotność, brak zrozumienia przez ludzi, bezsilność, starcza apatia i rezygnacja. Te wiersze samotnika, żyjącego w nędzy, prawie odciętego od świata, przynoszą wiele piękna przez swoją bezpośredniość" ${ }^{43}$. Warto w tym kontekście przytoczyć utwór Do astmy, w którym poeta dokonuje personifikacji choroby, na którą zapadł pod koniec życia. Nieproszonego gościa poeta przywitał nieco markotnym sonetem, porównując go do drapieżnej kobiety, do diablicy męczącej starzejącego się twórcę:

Astmo, djablico, czego chcesz odemnie?

Zaco mnie męczysz tak i tyle czasu?

Czy zato, żem się ubiegał darmnie

O marną sławę, o marę Parnasu?

Czy, żem się duchem bracił potajemnie

$\mathrm{Z}$ duchami góry, doliny i lasu?

Czy, żem po miłość chodził w serca ciemnie,

Jak po truciznę w pustynie upasu?

Widzisz, ni lauru ani mirtu u mnie;

Jak dla zająca, dla mnie grzbiet przyjaźni;

Fortuna, pustą tylko błyskawicą,

Lub ogniem błędnym oczy moje draźni;

I w świecie dla mnie jakby w świata trumnie.

Czemu mnie męczysz, czego chcesz, djablico? ${ }^{44}$

Refleksje podmiotu lirycznego są pełne tragizmu i goryczy, może typowego starczego rozdrażnienia, lecz nie ma w nich śladów załamania psychicznego. Pojawia się w nich natomiast uczucie rozczarowania oraz wyraźna świadomość nieuchronnego końca ziemskiej wędrówki.

Jak napisał Norwid, „Tomasz August Olizarowski policzony jest palcem dziejów do grona tych poetów, którzy nie ocenioną przez krytyków próbę wytrzymali" ${ }^{45}$. Był on niewątpliwie jasną postacią literatury polskiej, która nie tylko dzięki swojej działalności literackiej, lecz także i patriotycznej, jeszcze za życia zasłużyła sobie na szacunek. Wspominał o tym Wincenty Budzyński, pisząc: „Sposób, w jaki się wyrażał, stanowczy, sarkastyczny, znamionujący potężny indywidualizm narodowy, odstręczał od niego kolegów; ale za to zjednywał mu u nichże samych potem stalszy, bo oparty na zdrowym

43 T. Sivert, Olizarowski i jego patriotyczna liryka emigracyjna, „Prace Polonistyczne” 1964, seria XX, s. 243.

44 T.A. Olizarowski, Do astmy, [w:] DRUBNWW, sygn. Ф. XXIV, 2600, dok. nr 7.

45 C.K. Norwid, Dwie aureole, „Poezja” 1983, nr 11-12, s. 4. 
poznaniu szacunek, którego już nic nie wzruszy"46. Dziś ten wybitny przedstawiciel „ukraińskiej szkoły” w romantyzmie polskim, a zarazem wielki polski patriota, jest już nieco przez historię literatury zapomniany. Jego twórczość wciąż czeka nie tylko na należyte opracowania, ale nade wszystko na zebranie oraz opublikowanie, najlepiej z krytyczną edycją, jak to miało miejsce w przypadku wydanego w Białymstoku zbioru poematów ${ }^{47}$. Pozostaje tylko mieć skromną nadzieję, że niniejszy przyczynek wniesie choć mały wkład do zbadania literackiej spuścizny po tym wielkim polskim pisarzu.

\section{BIBLIOGRAFIA}

Bielanka-Luftowa Maria. 1936. Znaczenie terytorium $w$ tak zwanej szkole ukraińskiej. „Pamiętnik Literacki” z. 2: 360-376.

Bobrowski Florian. 1905. Stownik tacińsko-polski. Wyd. 3. Wilno: J. Zawadzki.

Budzyński Wincenty. 1846. Kilka uwag o poezji narodowej z powodu nowo wydanych „,Woskresenek” Tomasza Augusta Olizarowskiego. Paryż: w Drukarni i Litografii Maulde i Renou.

Burzka-Janik Małgorzata. 2014. Mistyczna frenezja. Czarny romantyzm Tomasza Augusta Olizarowskiego. W: T.A. Olizarowski. Poematy. Red. Burzka-Janik M., Ławski J. Białystok: Alter Studio: 9-132.

Dubiecki Marian. 1893. Tomasz Olizarowski. „Przegląd Powszechny” t XXXVII, nr 109: 52-69.

Duchińska Seweryna. 1897. Tomasz August Olizarowski. „Biblioteka Warszawska” t. IV: $1-35$.

Elektroniczny słownik języka polskiego XVII i XVIII wieku. Polska Akademia, Instytut Języka Polskiego. W: http://sxvii.pl/index.php?strona=haslo\&id_hasla=2287 [dostęp: 22.09.2017].

Êršov Volodimir. 2007. Volins'kij prostìr u memuarističnij literaturì Pravoberežžâ. „Volin'-Žitomirŝina”. İstoriko-fillologičnij zbìrnik z regìonal'nih problem nr 17: 2138 [Сршов Володимир. 2007. Волинський простір у мемуаристичній літературі Правобережжя. „Волинь-Житомирщина”. Історико-філологічний збірник з регіональних проблем $\mathrm{nr}$ 17: 21-38].

Gomulicki Juliusz Wiktor. 1983. Tomasz August Olizarowski (1811-1879). „Poezja” nr 1112: 7-8.

Gorkowski Kanut. 1983. Przemówienie K(anuta) Gorkowskiego nad grobem T(omasza) Olizarowskiego w Montmorency 21 maja 1886 r. „Poezja” nr 11-12: 196-197.

Grabowski Michał, O szkole ukraińskiej poezyi. W: Idem, Literatura i krytyka, Wilno 1839, s. 11.

Kamińska Anna Elżbieta. 2005. Krzemieniec Tomasza Augusta Olizarowskiego. „Rocznik Towarzystwa Literackiego imienia Adama Mickiewicza" nr 40: 155-168.

Kirčìv Roman. 2003.,,Ukraïns'ka škola” pol's'kogo romantizmuv kontekstìmižnacional'nih fol'klorno-literaturnih vzaêmin. „Kiïvs'kì polonìstičnì studiī” t. V: Romantizm: mìž

46 W. Budzyński, Kilka uwag o poezji narodowej z powodu nowo wydanych , Woskresenek” Tomasza Augusta Olizarowskiego, Paryż 1846, s. 24.

47 T.A. Olizarowski, Poematy, red. M. Burzka-Janik, J. Ławski, Białystok 2014, 930 s. 
Ukraïnoû ta Pol'ŝeû: 22-59 [Кирчів Роман. 2003. „Українська школа” польського романтизму в контексті міжнаціональних фольклорно-літературних взаємин. „Київські полоністичні студіі” t. V: Романтизм: між Украӥною та Польщею: 22-59].

Kulawik Adam. 1997. Poetyka. Wstęp do teorii dzieła literackiego. Kraków: Antykwa.

Markiewicz Zygmunt, Sivert Tadeusz. 1973. Melpomena polska na paryskim bruku. Teatralia polskie we Francji w XIX wieku. Warszawa: PWN.

Norwid Cyprian Kamil. 1983. Dwie aureole. „Poezja” nr 11-12, s. 3-5.

Olizarowski (Tomasz August). W: Encyklopedyja powszechna. 1865. T. XIX: Msta. - Optymaci. Warszawa: Nakładem S. Orgelbranda: 878-879.

Olizarowski Tomasz August (1811-1879). W: Dawni pisarze polscy od początków piśmiennictwa do Młodej Polski. Przewodnik biograficzny i bibliograficzny. 2002. T. 3: Mia-R. Warszawa: Fundacja Akademia Humanistyczna: 175-176.

Olizarowski Tomasz August. 1852. Dzieła t. 1. Wrocław: Nakładem Zygmunta Schlettera.

Olizarowski Tomasz August. 2014. Poematy. Red. Burzka-Janik M., Ławski J., Białystok: Alter Studio.

Olizarowski Tomasz August. Błędna mara. W: DRUBNWW. Sygn. Ф. XXIV, 2600, dok. nr 9.

Olizarowski Tomasz August. Do astmy. W: DRUBNWW. Sygn. Ф. XXIV, 2600, dok. nr 7.

Olizarowski Tomasz August. Do Polski. W: DRUBNWW. Sygn. Ф. XXIV, 2600, dok. $\mathrm{nr} 1$.

Olizarowski Tomasz August. Nieco o zimie. W: DRUBNWW. Sygn. Ф. XXIV, 2600, dok. nr 1.

Olizarowski Tomasz August. W: Polski słownik biograficzny 1978. T. XXIII: Niemirycz Władysław - Olczak Wacław. Wrocław - Warszawa - Kraków - Gdańsk: Zakład Narodowy im. Ossolińskich: 823-824.

Rudkowska Magdalena. 1998. Tomasza Augusta Olizarowskiego szansa na dramat narodowy. „Teksty Drugie” nr 5: 125-136.

Sivert Tadeusz. 1964. Olizarowski i jego patriotyczna liryka emigracyjna. „Prace Polonistyczne" t. XX: 235-244.

Szkoła ukraińska w romantyzmie polskim. Szkice polsko-ukraińskie. 2012. Red. Makowski S., Makowska U., Nesteruk M. Warszawa: Wydział Polonistyki Uniwersytetu Warszawskiego.

Tchórzewski Andrzej. 1983. Dwaj poeci. Kroki z korytarza nicości. „Poezja” nr 11-12: 108-121.

Tyszyński Aleksander. 1837. O szkołach poezii polskiej. W: A. Tyszyński. Amerykanka w Polsce. Romans cz. 2. St. Petersburg: W Drukarni Karola Kraya:17-108.

Varfolomeêva Nelâ. 2011. Ratio contra cordo. Geneza obrazu „slov 'âns'koï vitčizni” u tvorčostì Tomaša Avgusta Olizarovs'kogo. „Kiïvs'kì polonìstičnì studiī” t. 18: 166173 [Варфоломеєва Неля. 2011. Ratio contra cordo. Генеза образу „слов'янської вітчизни” у творчості Томаша Августа Олізаровського. „Київські полоністичні студії" t. 18: 166-173].

Wasilenko Włodzimierz. 1993. Nieznane polonica w ukraińskich archiwach. „Ruch Literacki" $\mathrm{nr}$ 4: 444-463.

Zbiór poetów polskich XIX w. 1959. Ułożył i opracował P. Hertz. T. II. Warszawa: Państwowy Instytut Wydawniczy.

Zieniewicz Andrzej. 1983. Biedna, romantyczna dusza. „Poezja” nr 11-12: 11-23. 


\section{POEMS BY TOMASZ AUGUST OLIZAROWSKI (FROM THE COLLECTIONS OF UKRAINIAN NATIONAL LIBRARY NAMED AFTER VOLODYMYR VERNADSKY IN KIEV)}

Summary. In this paper the author is trying to presenting the figure of a Polish romanticist, a representative of the "Ukrainian school" in Polish literature, and also a prominent socio-cultural activist in exile, Tomasz August Olizarowski. In the first part of the work the author presents selected elements of the writer's biography and his the most important literary works. The second part of this paper contains reflections on the manuscript of poems, found in the Manuscripts Department of the National Ukrainian Library named after Volodymyr Vernadsky in Kiev. The confrontation of the found works with the existing state of knowledge allowed to correct some inaccuracies, especially regarding the titles of the mentioned poems. It seems that this work can be regarded as a small contribution to the study of the literary legacy of T.A. Olizarowski.

Key words: "Ukrainian school" in Polish literature, poetry, poems, romanticism, Polish emigration

\section{ВІРШІ ТОМАША АВГУСТА ОЛІЗАРОВСЬКОГО (ІЗ ФОНДІВ НАЦІОНАЛЬНОЇ БІБЛІОТЕКИ ІМ. ВОЛОДИМИРА ВЕРНАДСЬКОГО В КИЄВІ)}

Анотація. Дана стаття присвячена висвітленню постаті польського романтика, представника “української школи” в польській літературі, а також видатного соціокультурного діяча в екзилі, Томаша Августа Олзаровського. У першій частині роботи автор представляє окремі елементи біографії письменника, творчу постать і найважливіші літературні твори. Друга частина статті містить роздуми над рукописом віршів, знайденим у Відділі рукописів Національної бібліотеки України ім. Володимира Вернадського в Києві. Конфронтація знайдених текстів з існуючим станом знань дозволила виправити деякі неточності, особливо щодо назв згаданих віршів. Автор має надію, що ця робота стане невеликим внеском у вивчення літературної спадщини Т. А. Олізаровського.

Ключові слова: “українська школа” в польській літературі, поезія, вірші, романтизм, еміграція 